\title{
Risk Estimation in the Greek Constructions’ Worksites by using a Quantitative Assessment Technique and Statistical Information of Occupational Accidents
}

\author{
P. K. Marhavilas * \\ Dep. of Production \& Management Engineering, Democritus Univ. of Thrace, Xanthi, Greece \\ Dep. of Electrical \& Computer Engineering, Democritus Univ. of Thrace, Xanthi, Greece
}

Received 24 March 2009; Revised 25 May 2009; Accepted 1 June 2009

\begin{abstract}
The risk estimation is a very crucial part of the whole procedure of evaluating hazards in the work. We can consider the risk as a quantity, which can be measured and expressed by a mathematical relation, under the help of occupational accidents' data. In this paper, we analyze a quantified risk estimation technique and apply on the constructions' worksites by using occupational accidents' statistical information of SEPE Service (Ministry of Employment) and IKA Social Insurance Institute (Ministry of Health). The outcome result of the risk value $\mathrm{R}$ has been estimated to be higher than 200 (in the risk gradation scale of 0-1000), for the time period 2000-2003, and proves that actions must be done earlier than 1 year, to degrade the likelihood of arising fatal accidents.

Keywords: risk analysis, risk estimation, risk assessment, quantitative risk assessment, quantified risk evaluation, construction worksite, occupational accident
\end{abstract}

\section{Introduction}

Risk has been defined as "the chance that someone or something that is valuated will be adversely affected by the hazard" [1]. A hazard is any unsafe condition or potential source of an undesirable event with potential for harm or damage [2]. Risk analysis is an essential tool for the safety policy of a company, and the risk estimation is the most important part of the whole procedure of hazards' evaluation in the work, and especially in the constructions' worksites, where the work conditions are unstable. In this paper, we analyze a quantified risk estimation technique and apply on the Greek constructions' worksites by using occupational accidents' statistical information of SEPE Service (Ministry of Employment) and IKA Social Insurance Institute (Ministry of Health), concerning years 2000-2003.

\section{Quantitative Assessment of Risk}

We can quantified the risk and consider it as a quantity, which can be measured and expressed by a mathematical relation [3], under the help of real accidents' data.

The quantitative calculation of the risk (or quantified risk evaluation) can be given (see [3], [5], [6], [7]) by the following relation:

$$
R=P \cdot S \cdot F
$$

where:
R: the Risk
P: the Probability Index
S: the Severity of Harm Index
F: the Frequency Index

Each factor in equation (2.1), takes values in the scale of 1-10 according to Tables $1,2,3$, so that the quantity $\mathrm{R}$ can be expressed in the scale of 1-1000 (see [3], [4]). Concerning the gradation of probability index $(\mathrm{P})$, the value $\mathrm{P}=1$ corresponds to probability of 0.1 or $10 \%, \mathrm{P}=2$ to probability of 0.2 or $20 \%$, etc. We note the possible existence of intermediate values, as a result of linear interpolation e.g. the value $\mathrm{P}=4.2$, corresponds to probability of 0.42 or $42 \%$.

We can use Table 4 to associate the gradation of the risk value $\mathrm{R}$ with the urgency level of required actions. To develop Table 4, we give values to Probability and Severity of Harm factors so that the Frequency (or Exposure) Factor could determine the urgency level of the required actions [3]. 
Table 1

Gradation of the Probability Index in association with the undesirable event

\begin{tabular}{c|l}
$\begin{array}{c}\text { Probability } \\
\text { Index }(\mathrm{P})\end{array}$ & \multicolumn{1}{c}{ Description of Undesirable Event } \\
\hline 10 & Unavoidable \\
\hline 9 & Almost assured \\
\hline 8 & Very Probable \\
\hline 7 & Probable \\
\hline 6 & Probability slightly greater than $50 \%$ \\
\hline 5 & Probability 50\% \\
\hline 4 & Probability slightly less than $50 \%$ \\
\hline 3 & Almost improbable \\
\hline 2 & Very improbable \\
\hline 1 & Improbable)
\end{tabular}

Table 2

Gradation of the Severity of Harm Index in association with the undesirable event

\begin{tabular}{c|l}
\hline $\begin{array}{c}\text { Severity of Harm } \\
\text { Index } \\
(S)\end{array}$ & \multicolumn{1}{c}{ Description of Undesirable Event } \\
\hline 10 & Death \\
\hline 9 & Permanent total inefficiency \\
\hline 8 & Permanent serious inefficiency \\
\hline 7 & Permanent slight inefficiency \\
\hline 6 & $\begin{array}{l}\text { Absence from the work }>3 \text { weeks, and return with } \\
\text { health problems }\end{array}$ \\
\hline 5 & $\begin{array}{l}\text { Absence from the work }>3 \text { weeks, and return after } \\
\text { full recovery }\end{array}$ \\
\hline 4 & $\begin{array}{l}\text { Absence from the work }>3 \text { days and }<3 \text { weeks, and } \\
\text { return after full recovery }\end{array}$ \\
\hline 3 & $\begin{array}{l}\text { Absence from the work <3 days, and return after } \\
\text { full recovery }\end{array}$ \\
\hline 2 & $\begin{array}{l}\text { Slight injuring without absence from the work, and } \\
\text { with full recovery }\end{array}$ \\
\hline 1 & No one human injury \\
\hline
\end{tabular}

Table 3

Gradation of the Frequency Index in association with the undesirable event

\begin{tabular}{c|l}
\hline $\begin{array}{c}\text { Frequency Index } \\
(\mathrm{F})\end{array}$ & \multicolumn{1}{c}{ Description of Undesirable Event } \\
\hline 10 & Permanent presence of damage \\
\hline 9 & Presence of damage every $30 \mathrm{sec}$ \\
\hline 8 & Presence of damage every $1 \mathrm{~min}$ \\
\hline 7 & Presence of damage every $30 \mathrm{~min}$ \\
\hline 6 & Presence of damage every $1 \mathrm{hr}$ \\
\hline 5 & Presence of damage every $8 \mathrm{hr}$ \\
\hline 4 & Presence of damage every $1 \mathrm{week}$ \\
\hline 3 & Presence of damage every 1 month \\
\hline 2 & Presence of damage every 1 year \\
\hline 1 & Presence of damage every 5 years \\
\hline
\end{tabular}

Table 4

Gradation of the Risk Value in association with the urgency level of required actions

\begin{tabular}{l|l}
\hline \multicolumn{1}{c|}{ Risk Value (R) } & \multicolumn{1}{c}{ Urgency level of required actions } \\
\hline $800-1000$ & Immediate action \\
\hline $600-800$ & Action during 7 days \\
\hline $400-600$ & Action during 1month \\
\hline $200-400$ & Action during 1 year \\
\hline$<200$ & $\begin{array}{l}\text { Immediate action is not necessary but it is } \\
\text { required the event surveillance }\end{array}$ \\
\hline
\end{tabular}

\section{Risk Estimation in the Constructions' worksites}

We proceed to the calculation of risk value $\mathrm{R}$ on the Greek constructions' worksites, by using the quantitative technique of equation (2.1) and occupational accidents' statistical information of SEPE Service (Hellenic Ministry of Employment) and IKA (Hellenic Ministry of Health), concerning the year 2002 (see Tables 5, 6) and the time period 2000-2003 (see Tables 7). Moreover Table 8 presents the calculation results of the total value $\mathrm{R}$ in the Greek constructions worksites for the period 2000-2003.

The Probability Index $(\mathrm{P})$ can be calculated (in column $\mathrm{C}$ of Tables 5,6) for various undesirable events (Column A) by using the corresponding number of accidents (Column B) and the following equation:

$P=\frac{\text { Number of accidents or undesirable events }}{\text { Total number of accidents }} \times 10$

The Severity of Harm Index (S) is estimated (in column D of Tables 5,6 ) for the worst case by using the gradation scale of Table 2 .

The Frequency Index (F) shows the number of accidents during a definite time period. In order to calculate the accidents' frequency (per day), we use data for 1 year time period (i.e. with 48 working weeks and each working week with 5 working days) in the relation:

$$
\text { Accid. Frequency }=\frac{\text { Number of accid. per event }}{48 \bullet 5}
$$

Then the Frequency Index (F) is calculated (in column $\mathrm{E}$ of Tables 5,6 ) by the combination of equation's (3.2) result, and the gradation scale of Table 3. Eventually, the risk value $\mathrm{R}$ for year 2002, is depicted in Column $\mathrm{F}$ of Tables 5, 6. Comparing tables 5, 6 (column F) we realize that the results for $\mathrm{R}$ are different. The reason is that these tables have been produced by two separated data-bases: Table 5 from the SEPE data-base, and Table 6 from the IKA one.

Furthermore, by using the above explained quantitative risk assessment technique, expressing by equations (2.1), (3.1), (3.2) and the accidents' data of SEPE in Table 7 (concerning years 2000-2003) we have calculated in Column $\mathrm{E}$ of Table 8, the total risk value $\mathrm{R}$ in the Greek constructions' worksites and Public Works. Furthermore, Table 7 represents the sample space, or in other words the set of all possible outcomes (i.e. undesirable events or accidents) for the Greek constructions worksites and Public Works, and it is used to calculate the probability index P. For example, as far as concern the year 2000, by using equation (3.1), and Table 7, where the number of accidents in the constructions worksites is $\mathrm{N}_{\mathrm{CW}}=66$ and the total number of accidents in the Greek worksites is $\mathrm{N}_{\mathrm{T}}=127$, we have the result of $\mathrm{P}=(66 / 127) \times 10=5.2$. To take into account the worst case, we give the maximum value $S=10$ to Severity of Harm Factor (S), while the Frequency Index (F) has been calculated by the usage of equation (3.2) and the gradation scale of Table 3 , so that $66 / 48=1.375$ accidents per working week, which corresponds to $F=4.1$ (according to Table 3 and in association with the using of linear interpolation for the intermediate values). 


\section{Discussion - Results - Comclusions}

The risk estimation is a very crucial part of the whole procedure of evaluating hazards in the work. We can consider the risk as a quantity, which can be measured and expressed by a mathematical relation, under the help of occupational accidents' data. In this paper, we analyze a quantified risk estimation technique (QRET) and apply on the Greek constructions' worksites by using occupational accidents' statistical information of SEPE Service (Ministry of Employment) and IKA Social Insurance Institute (Ministry of Health).

To develop the above referred quantitative risk assessment technique, we used but improved specific points (like gradation scales, equations, and estimated factors) of other works included in the scientific literature [e.g. the papers of Fine and Kinney (1971), Hammer (1972), and Marhavilas and Koulouriotis (2008)].

The outcome results of the risk estimation $\mathrm{R}$ for year 2002, according to the QRET technique (Table 6, column F) show that the most important hazard source in the Greek Constructions' Worksites and Public Works, according to IKA data-base, is the "Impacts on stable objects, hits by moving objects" (with $\mathrm{R}=215.7>200$ ) and proves that required actions must be done earlier than 1 year, to degrade the likelihood of arising fatal accidents.
Moreover, the maximum outcome result of the risk value $\mathrm{R}$ in the Greek constructions' worksites and Public Works, according to SEPE data-base, which concerns the period of years $2000-2003$, is $\mathrm{R}=228.8>200$ (Table 8 ) and proves that actions must be done earlier than 1 year, to degrade the likelihood of arising fatal accidents.

Comparing tables 5, 6 (column F) we realize that the results for $\mathrm{R}$ are different. The reason is that these tables have been produced by two separated data-bases: Table 5 from the SEPE data-base, and Table 6 from the IKA one.

The contribution and merit of this work to the health and safety science, could be focused on the following points:

On the risk prediction and prevention: The use of the abovepresented new quantitative risk assessment technique could help the responsible persons of a work-site (directors, safety managers/engineers, etc) to predict hazards, unsafe conditions and undesirable events/situations, and also to prevent fatal accidents.

On the application of this new technique, for the first time on the Greek Constructions' Worksites and Public Works (as a case study), in such a way which makes the new technique useful tool for the quantitative risk estimation.

As a general conclusion, the development of an integrated risk analysis scheme, which will combine a wellconsidered selection of widespread techniques (including the QRET and others) would enable the safety engineers to achieve more efficient results on risk identification.

Table 5

Accident's statistical information of Hellenic Ministry of Employment according to report of SEPE of year 2002 (columns A, B), estimation of index S (col. D), and calculation of indices P, F (col. C, E) and risk value R (col. F)

\begin{tabular}{|c|c|c|c|c|c|}
\hline (A) & (B) & (C) & (D) & (E) & $(\mathrm{F})$ \\
\hline Description of Undesirable Event & $\begin{array}{l}\text { Number of } \\
\text { Accidents }\end{array}$ & $\begin{array}{l}\text { Probability Index } \\
\text { (P) }\end{array}$ & $\begin{array}{l}\text { Severity of Harm } \\
\text { Index (S) }\end{array}$ & $\begin{array}{l}\text { Frequency Index } \\
(\mathrm{F})\end{array}$ & $\begin{array}{l}\text { Risk Value } \\
(\mathrm{R})\end{array}$ \\
\hline Drops (Slumps from height) & 325 & 3,07 & 10 & 5,05 & 155,1 \\
\hline Downfalls (at the same level) & 130 & 1,23 & 8 & 4,43 & 43,5 \\
\hline Slips, hits by dropping objects & 181 & 1,71 & 10 & 4,96 & 84,9 \\
\hline $\begin{array}{l}\text { Impacts on stable objects, hits by moving } \\
\text { objects }\end{array}$ & 93 & 0,88 & 9 & 4,23 & 33,5 \\
\hline Squeezing & 111 & 1,05 & 9 & 4,33 & 40,9 \\
\hline Overworking, hard jobs & 25 & 0,24 & 7 & 3,36 & 5,6 \\
\hline $\begin{array}{l}\text { Exposure/Contact in/with extreme } \\
\text { temperatures }\end{array}$ & 10 & 0,09 & 7 & 2,94 & 1,9 \\
\hline Exposure/Contact in/with electric current & 27 & 0,26 & 10 & 3,42 & 8,7 \\
\hline $\begin{array}{l}\text { Exposure/Contact in/with harmful } \\
\text { substances or radiation }\end{array}$ & 3 & 0,03 & 9 & 2,75 & 0,7 \\
\hline Other reasons of accidents & 153 & 1,45 & - & & \\
\hline Total & 1.058 & 10,00 & & & \\
\hline
\end{tabular}

Table 6

Accident's statistical information of Hellenic Ministry of Health according to report of IKA of year 2002 (columns A, B, estimation of index S (col. D), and calculation of indices P, F (col. C, E) and risk value R (col. F)

\begin{tabular}{|c|c|c|c|c|c|}
\hline (A) & (B) & (C) & (D) & (E) & $(\mathrm{F})$ \\
\hline Description of Undesirable Event & $\begin{array}{l}\text { Number of } \\
\text { Accidents }\end{array}$ & $\begin{array}{l}\text { Probability Index } \\
\text { (P) }\end{array}$ & $\begin{array}{l}\text { Severity of Harm } \\
\text { Index }(\mathrm{S})\end{array}$ & $\begin{array}{l}\text { Frequency Index } \\
\text { (F) }\end{array}$ & $\begin{array}{l}\text { Risk Value } \\
\text { (R) }\end{array}$ \\
\hline Drops (Slumps from height) & 2.141 & 1,34 & 10 & 6,12 & 81,7 \\
\hline Downfalls (at the same level) & 2.561 & 1,60 & 8 & 6,33 & 80,9 \\
\hline Slips, hits by dropping objects & 1.880 & 1,17 & 10 & 5,98 & 70,1 \\
\hline $\begin{array}{l}\text { Impacts on stable objects, hits by moving } \\
\text { objects }\end{array}$ & 5.477 & 3,42 & 9 & 7,01 & 215,7 \\
\hline Squeezing & 2.501 & 1,56 & 9 & 6,30 & 88,5 \\
\hline Overworking, hard jobs & 501 & 0,31 & 7 & 5,16 & 11,3 \\
\hline Exposure/Contact in/with extreme temperat. & 311 & 0,19 & 7 & 5,04 & 6,8 \\
\hline Exposure/Contact in/with electric current & 58 & 0,04 & 10 & 4,05 & 1,5 \\
\hline $\begin{array}{l}\text { (Exposure/Contact in/with harmful } \\
\text { substances or radiation }\end{array}$ & 245 & 0,15 & 9 & 5,00 & 6,9 \\
\hline Other reasons of accidents & 356 & 0,22 & - & 5,07 & - \\
\hline Total & 16.031 & & & & \\
\hline
\end{tabular}


Table 7

Statistical information of fatal accidents of Hellenic Ministry of Employment (according to report of SEPE of years 2000, 2001, 2002, 2003) for various categories of financial activities

\begin{tabular}{|c|c|c|c|c|c|}
\hline Code & $\begin{array}{l}\text { Description of various financial branches } \\
\text { (according to STAKOD-91 coding) }\end{array}$ & Year & Year & Year & Year \\
\hline & & 2000 & 2001 & 2002 & 2003 \\
\hline 1 & Agriculture-stock farming & 5 & 9 & 7 & 0 \\
\hline 2 & Forestry - woodcutting & 2 & 2 & 0 & 0 \\
\hline 5 & Fishing & 2 & 4 & 0 & 0 \\
\hline 10 & Mines - quarryes & 2 & 3 & 1 & 0 \\
\hline 14 & Other mining and quarrying activities & 0 & 0 & 1 & 1 \\
\hline 15 & Industries of foods and drinks & 3 & 10 & 9 & 5 \\
\hline 16 & Tobacco products & 1 & 0 & 0 & 1 \\
\hline 17 & Textile production & 0 & 0 & 2 & 2 \\
\hline 18 & Production of clothes & 0 & 1 & 1 & 0 \\
\hline 20 & Wood industries & 0 & 1 & 1 & 1 \\
\hline 21 & Production of wood-pulp, paper, cardboard & 0 & 1 & 1 & 2 \\
\hline 22 & Editions, impressions & 0 & 0 & 1 & 0 \\
\hline 23 & Production of oil-products & 0 & 0 & 2 & 2 \\
\hline 24 & Production of chemical substances & 1 & 1 & 2 & 1 \\
\hline 25 & Rubber industries and production of plastic matter & 1 & 1 & 0 & 2 \\
\hline 26 & Industries of non-metallic minerals & 9 & 3 & 5 & 9 \\
\hline 27 & Production of metals & 4 & 4 & 0 & 6 \\
\hline 28 & Manufacture of metallic products (except machines) & 3 & 3 & 8 & 5 \\
\hline $\begin{array}{l}29 \\
31 \\
\end{array}$ & Machine and equipment construction & 0 & 3 & 4 & 2 \\
\hline 32 & Production of Radio \& TV device & 1 & 0 & 0 & 0 \\
\hline 34 & Car industries and construction of vehicle trailer & 0 & 1 & 1 & 1 \\
\hline 35 & Construction of transportation equipment & 3 & 7 & 5 & 3 \\
\hline 36 & Furniture production & 0 & 2 & 0 & 0 \\
\hline 40 & Supply of electric energy and natural gas & 6 & 3 & 6 & 3 \\
\hline 41 & Companies of water supplying & 1 & 0 & 0 & 0 \\
\hline 45 & Constructions' Worksites - Public Works & 66 & 86 & 80 & 79 \\
\hline 50 & Car commerce, car-bike repairing, fuel station & 2 & 2 & 1 & 0 \\
\hline 51 & Wholesale trade & 3 & 4 & 4 & 3 \\
\hline 52 & Retail trade - Repairing of domestic kinds & 2 & 4 & 4 & 2 \\
\hline 55 & Hotels - Restaurants & 2 & 2 & 2 & 0 \\
\hline 60 & Land Transportations & 1 & 9 & 1 & 3 \\
\hline $\begin{array}{l}61 \\
62 \\
\end{array}$ & Water Transportations & 0 & 1 & 2 & 1 \\
\hline 63 & Relative to transportations activities - Storages & 0 & 3 & 2 & 1 \\
\hline 64 & Telecommunications- Posts- Mails & 2 & 4 & 1 & 3 \\
\hline 71 & Machines leasing & 0 & 1 & 0 & 0 \\
\hline 74 & Other enterprising activities & 2 & 2 & 2 & 2 \\
\hline 75 & Public administration - Health insurance & 0 & 3 & 2 & 1 \\
\hline 80 & Education & 0 & 2 & 0 & 0 \\
\hline 85 & Health \& Social Care & 0 & 1 & 0 & 0 \\
\hline 90 & Waste disposal & 1 & 3 & 1 & 3 \\
\hline 92 & Entertainment, culture \& sport activities & 1 & 0 & 1 & 1 \\
\hline 95 & Other activities of ministration & 1 & 1 & 0 & 0 \\
\hline \multirow[t]{2}{*}{99} & Other enterprises & 0 & 1 & 0 & 0 \\
\hline & Total & 127 & 188 & 160 & 145 \\
\hline
\end{tabular}


Table 8

Calculation results of the total risk value $\mathrm{R}$ in the Greek constructions' worksites \& Public Works, concerning years 20002003, by using the quantitative risk assessment technique (equations 2.1, 3.1, 3.2) and occupational accidents' data of SEPE/Hellenic Ministry of Employment of Table 7.

\begin{tabular}{|c|c|c|c|c|}
\hline (A) & (B) & (C) & (D) & (E) \\
\hline Year & $\begin{array}{l}\text { Probability Index } \\
\text { (P) }\end{array}$ & $\begin{array}{l}\text { Severity of Harm Index } \\
\text { (S) }\end{array}$ & $\begin{array}{l}\text { Frequency Index } \\
\text { (F) }\end{array}$ & $\begin{array}{l}\text { Risk Value } \\
\text { (R) }\end{array}$ \\
\hline 2000 & 5,2 & 10 & 4,10 & 213,2 \\
\hline 2001 & 4,6 & 10 & 4,20 & 193,2 \\
\hline 2002 & 5,0 & 10 & 4,20 & 210,0 \\
\hline 2003 & 5,5 & 10 & 4,16 & 228,8 \\
\hline
\end{tabular}

\section{References}

1. Woodruff, J. M., Consequence and likelihood in risk estimation: A matter of balance in UK health and safety risk assessment practice, Safety Science, 43, 345-353, (2005).

2. Reniers, G.L.L., W. Dullaert, B.J.M Ale, K. Soudan, Developing an external domino prevention framework: Hazwim. Journal of Loss Prevention in the Process Industries, 18, 127-138, (2005).

3. Marhavilas, P.K., D.E. Koulouriotis, A risk estimation methodological framework using quantitative assessment techniques and real accidents' data: application in an aluminum extrusion industry", Journal of Loss Prevention in the Process Industries, ISSN:0950-4230

doi:10.1016/j.jlp.2008.04.009, vol 21, 6, 596-603, (2008).
4. Arvanitogeorgos A., Risk analysis in Industry, Greek Institute of Health and Safety in the Work, ELINYAE, ISBN 960-7678-16-2, (1999).

5. Fine, W.T. and W.D. Kinney, Mathematical evaluation for controlling hazards, Journal of Safety Research, 3 (4), 157-166, (1971).

6. Hammer, R.W., Handbook of system and products safety, Englewood Cliffs, N.J.: Prentice-Hall, Inc., (1972).

7. Marhavilas, P.K., Health and Safety in the Work - Handling of the Professional Danger, Tziolas Edition, ISBN 978-960-418-171-1, pages 289, (2009). 